\title{
Can caesarean section be 'natural'? The hybrid nature of the nature-culture dichotomy in mainstream obstetric culture
}

\section{Irene Maffi}

The University of Lausanne, Switzerland irene.maffi@unil.ch

Maffi, I (2013). Can caesarean section be 'natural'? The hybrid nature of the natureculture dichotomy in mainstream obstetric culture . Tidsskrift for Forskning i Sygdom og Samfund, nr. 19, 5-26.

Reflecting on the recent creation of the surgical technique of 'natural caesarean', this paper investigates how caesarean section, a major abdominal surgery, can be associated with 'natural childbirth' To understand the paradoxical creation of this concept, I look back at the history of obstetrics and at the evolution of the nature/culture dichotomy in European modern thought. The multiple meanings of these two concepts and the epistemological and social premises underpinning the formation of modern obstetrics are examined to unravel the complexity of current medical practices applied to women's bodies as well as women's attitudes. In light of these historical elements, natural caesarean is understood as a notion born from cultural and professional negotiations and fraught with contradictory meanings originating from different medical and cultural discursive traditions. 


\section{'Natural caesarean' as a configuration of roles}

In the 2000s, Professor Nicholas Fisk, an obstetrician at Queens Charlotte in London, performed what he and his team have called a 'natural caesarean', that is an abdominal surgery that they regarded as 'a series of measures to mimic the situation at vaginal birth' (Smith et al 2008: 1040). According to the designers of 'natural caesarean', three main characteristics connect this operation to what is usually called 'natural birth'. First, parents can see their baby when she/he is extracted from the mother's abdomen, since the drape "that "divorced" the upper part of her body from the birthing scene is dropped at the right moment'. Second, the baby is extracted slowly so that s/he "is able to "autoresuscitate" -start breathing unaided' (Edwardes 2009: 1). Third, the newborn is immediately handed to the mother for the skin-to-skin first contact allowing 'bonding', a practice that today is standardised in several European countries after a woman has had a vaginal birth. Furthermore, as stated by one member of Professor Fisk's team, 'the father can perform a second "cutting of the cord" and the midwife can show him where to clamp it' (ibid: 2). The aim is to encourage mother and father to be 'active participants in the birth of their child' instead of undergoing the surgical event passively (Smith et al. 2008: 1040). Yet the idea of participation is complex and needs to be deconstructed in order to understand what it exactly means. Fisk seems to use the expression 'active participation' first of all to indicate that both parents can witness visually and hence emotionally the baby's surgical extraction. Besides, the active role of the father consists of cutting the cord and supporting the baby once $\mathrm{s} /$ he is put on the mother's chest, while the mother can have the new-born put on her chest but is not permitted to 'reach out for the baby, as this risks touching the obstetrician' (ibid: 1039). Despite the aim of enhancing parent's participation, rigid norms define the appropriate behaviour in the operating theatre: 'active participation' is thus delimited by medical staff's needs as well as by the material and hygienic constraints of the surgical setting. More broadly, the notion of parents' participation has to be associated with the model of 'natural/normal birth' as it is conceived of and practised in many European hospitals where each member of the family has to play her/his role.

For example in a Swiss hospital where I have been conducting fieldwork since 2011 , the roles parents have to play at birth are usually explained during childbirth classes to prepare couples to follow hospital rules and routines (Maffi, forthcoming). The roles couples are taught are different according to the type of birth, although several elements are common to the three main situations described by 
educators: spontaneous vaginal birth, induction of labour, C-section. The task of the woman's partner is almost invariably presented as that of supporting the birthing woman and replacing her when she is unable to take care of the child after birth, such as in case of C-section, where the father is asked to practice the skinto-skin contact with the baby while the mother is in the operating theatre. In case of vaginal birth, the labouring woman has to abide by several rules that are not negotiable within the hospital such as accepting the systematic intravenous drip and the position for the delivery the midwife in charge will prefer, etc. She has also to prepare herself for childbirth, acquiring the knowledge of the physiology and anatomy deemed necessary, and to learn how to behave during labour and delivery, what are the benefits of breastfeeding, how to take care of her and of her child, etc. The new-born is also supposed to play a role: the large majority of babies born vaginally are put at their mother's breast immediately after birth to learn how to suck under the careful supervision of the midwife who tries to stimulate the child, manipulating his/her body in various ways. It is common for the midwives and nurses I have observed in the maternity ward to say to the baby immediately after birth that 's/he has now to do his/her work' sucking the mother's milk. A baby who does not 'work' as s/he should according to hospital protocols is gently reprimanded and constantly monitored and stimulated in order to fulfil his/her 'task'.

The standardisation of parents' roles during surgical birth is apparent when reading the testimonies left by number of French and Swiss mothers on the website césarine.net. Their stories explain in detail how the birth of their child happened and what they and their partner did, felt and experienced before, during and after the operation. The model these women describe is one in which the parturient woman is supposed to be 'awake and aware' during the operation in order to see her baby coming out and thus participate in the birth event, but also one in which she has to be patient and wait several hours before being able to see her baby. In most testimonies, hospital practices impose a long separation of mother and baby after the operation, while the father is assigned the role of replacing her partner in order to accompany the new-born in the first hours after birth. On the contrary, women's narrations do not attribute any specific role to the child after the operation. S/he is mostly presented as an object of their desire and despair, someone they would like to see and keep in their arms and from whom they are separated. The comparison between the model of C-section described in the testimonies posted on the website césarine.net and the description of 'natural 
caesarean' gives already a glimpse of the reasons that have prompted the creators of this procedure to define it as 'natural'.

\section{The nature of 'natural caesarean'}

Despite the adoption of more humanised procedures, how is it possible that Csection -defined by Fisk and his team as 'a most unnatural form of birth' (Smith et al 2008: 1040)- a major abdominal surgery requiring an operating theatre, the intervention of skilled personnel, the administration of anaesthesia and analgesics, and a hospital stay of several days, can be associated with 'natural childbirth'? To understand the paradoxical expression of 'natural caesarean', it is necessary to look back at the history of obstetrics and its techniques. Although the origin of C-section dates back at least to the Roman time when it was practised on dead women to extract the foetus (Pundel 1969), it was not until the second half of the 20th century that it became safer to perform it in order to save the life of the mother and of the baby. The 'normalisation' of this operation dates back to the 1970s when the C-section rates in the United States and in many European countries started to climb, rendering it's use banal and making women familiar with the idea of giving birth from above (Sargent et Stark 1987, De Koninck 1990). Technical improvements in surgery, anaesthesia and more generally in medicine such as blood transfusion, safer intravenous drips and the introduction of antibiotics are among the factors that have made possible the integration of C-section in the 'normal' technology of childbirth (Odent 2004: 10).

Indeed C-section, one of today's most common surgical operations in many European countries and North America (Jukelevics 2008), is now deemed a normal(ised) procedure, a routine practice that is not performed exclusively to save the life of the mother and of the baby, as it was originally conceived for, but also for various non medical reasons. According to the vast literature on the subject, several other causes have determined the high rate of C-section around the world (Souza et al 2010) such as convenience of the physician, hospital organisational constraints, economic benefit of health care providers and clinics, health inequalities and maternal request (Declercq et al 2011, Gamble et al 2007, Jacques 2007, Béhague 2002). Although since the 1980s national and international institutions have criticised the liberal use of surgical birth across the world (Betran et al 2007, Wagner 1994, WHO 1985), the creation of 'natural caesarean' is consistent with the general trend in obstetrics that consists in engaging with the moral imperative to make it more 'natural' or, according to another term, more 'humanised' rather 
than less frequent (Goer 2004). As mentioned above, for Dr. Fisk and his team, to make it more 'natural', C-section has to mimic as far as possible a hospital vaginal birth.

Since a British team created the procedure of 'natural caesarean' it is necessary to look at the definition of 'natural' or 'normal' birth in this country in order to understand the precise meaning of the term. The consensus statement reached in 2007 by the Maternity Care Working Party states that normal birth is 'without induction, without the use of instruments, not by caesarean section and without general, spinal or epidural anaesthetic before or during delivery' (Making Normal Birth a Reality: 1). While Darra (2009) shows that there is no clear consensus about what 'natural' or 'normal' childbirth is, since according to their training and professional category, birth attendants give different definitions of normal/natural childbirth, British professional organisations agree about the fact that childbirth is to be woman centred. For instance, the Royal College of Midwives states that 'Woman-centred care is the term used to describe a philosophy of maternity care that gives priority to the wishes and needs of the user, and emphasises the importance of informed choice, continuity of care, user involvement, clinical effectiveness, responsiveness and accessibility' (RCM 2011: 1).

Indeed, according to Fisk and his team, to be 'natural' a C-section needs to be a 'woman-centred technique' because it makes the surgical experience more satisfactory for the mother, preventing 'bonding difficulties and unsuccessful breastfeeding' (Smith et al 2008: 1037). The accommodation of the ordinary surgical technique to a more 'natural' and 'woman centred' model seems to indicate the current widespread medical and social acceptance of C-section in many countries where women as well as physicians regard surgery and more generally interventions during the birthing process as part of the necessary routine (Green and Baston 2007, Habiba et al 2006). While in some countries it has become very frequent and relatively safe to give birth by C-section, it is impossible to deny that the material and emotional conditions under which it happens continue to be quite different. For instance, although the mother is generally under spinal anaesthesia, a technique that numbs only the lower part of her body, and thus is awake during the surgery, she will usually not see her baby coming out, because a drape separate her head from her abdomen. Moreover, she is under the effect of tranquillisers and analgesics to help her facing the frightening atmosphere of the operating theatre and the sensation of her body being opened. Also her partner finds himself in an uncomfortable position, he has to wear special clothes, a mask and a cap, has to stand in the operating theatre next to the upper part of his 
partner's body without interfering with the event going on, he is often nervous at the prospect of attending a surgical operation and is seldom able to accomplish the nowadays almost normative act of cutting the umbilical cord. In addition it is not unusual for the baby to need assistance because s/he cannot breathe autonomously (Goer 1999, Wagner 2000). As a consequence, C-section does not allow the immediate skin-to-skin contact deemed beneficial in promoting bonding between mother and baby (Odent 2001). In light of these considerations, the new technique developed by Dr Fisk and his team contribute to the further normalisation of Csection, turning it from a major abdominal operation into what is considered a hospital 'natural birth'.

It is worth noting that the 'naturalisation' of this surgical procedure is today appreciated even by advocates of the 'natural birth model' such as doula Rebecca Bates who in 2011 has published in her blog an article praising the procedure created by Dr Fisk (http://rebeccabatesdoula.blogspot.ch/2011/06/natural-caesarean-important-reform.html). According to her, natural C-section is an improvement on the ordinary surgical procedure in that it allows the mother to see the baby coming out of her belly, experience the skin-to skin contact with the baby already in the operating room, to move freely her arms, while the baby is given the possibility of 'walking out' like in a vaginal birth and the father can cut the cord if he wishes. Bates remarks that natural C-section differs in many ways from ordinary procedures during which the woman can not see what happens, can not move her arms because of heavier doses of anaesthetics and the presence of several machines controlling her condition hooked in the upper part of her body. Moreover, after the delivery, the baby is quickly shown to the mother and transferred to another room together with the father. Subject to the health of mother and baby, the time of separation between the woman and her child can last one or more hours according to the hospital routines as confirmed for example by the already cited testimonies posted on the website césarine.net.

\section{The invention of 'natural childbirth'}

What the expression 'natural birth' means varies according to the profession, the historical period, the country, the setting where the delivery takes place and the actors who are involved (Davis-Floyd et al 2009, MacDonald 2007, Mansfield 2008, Moscucci 1993). Although 'natural caesarean' is constructed as a mirror of what is considered 'natural' or 'normal' birth, the latter are ambiguous terms used to designate dissimilar events that do not refer to the same setting, actors and practices 
(Darra 2009, Young 2009, Downe 2008). In order to understand the meaning of the nature/culture dichotomy in current obstetrics as expressed by the new technique of 'natural caesarean', I will evoke some elements that have contributed to the fabrication of the concept of 'natural childbirth' so as to instil a better understanding of the present debate.

The first to introduce the idea of 'natural childbirth' was the British physician Grantly Dick-Read, who defined it as 'one part of a continuum of normal physiological events representing and illustrating the two basic laws of the continuance of species, namely, the law of reproduction and the law of maintenance of the species. Natural childbirth means normal physiological childbirth' (1985: 20). Despite the adjective 'natural', Dick-Read pointed out that this kind of birth needs the preparation of the mother and of her partner, as well as of the medical team, and a specific arrangement of the hospital setting where labour and delivery have to take place. He used the adjective 'natural', because he thought that the preparation of all the actors would allow 'modern' or 'cultured' women to experience childbirth in their 'original' or 'primary' ways like their 'indigenous' sisters who were not touched by the western process of 'civilisation' and thus were closer to the primitive 'natural' state. Dick-Read regarded the 'primitive' woman as physically and psychologically more apt to have easy and less painful deliveries, because of a healthier lifestyle and a simple (non medical) representation of the birthing event. He insisted on the fact that 'modern childbirth is physically unaltered from earlier times, but our culture has brought to bear upon this function, neuromuscular activities caused by intensifying certain emotions that inhibit the progress of the birth and thus create pain. Yet there is no reason why culture should be allowed to destroy all that is beautiful in the primitive' (ibid: 158). Hence, he deemed the preparation of women before childbirth as necessary to retrieve the 'natural law of childbirth' that had been destroyed by modern (western) culture. His arguments reflect widespread stereotypes about 'primitive' women who at the time were considered as being closer to nature than western women (Coslett 1994; Moscucci 2003). While in modern European thought women were considered as closer to nature than men (MacCormack and Strathern 1980), primitive women were seen almost as female mammals giving birth as easily as other 'natural' beings.

In the 1950s, 1960s and 1970s other physicians became advocates of 'natural childbirth' among whom the French Ferdinand Lamaze, Frédéric Leboyer and Michel Odent played a prominent role. Influenced by Russian studies about mental conditioning, Lamaze created a method called obstetric psychoprofylaxis his aim was to allow women to experience childbirth without pain (1956). His method 
had a strong impact on birth practices in Western Europe as well as in the United States, where the creation of the Lamaze International Institute transformed it into a professional domain. While Lamaze's main concern was about birthing women, Leboyer focused on the new-borns' medical treatment at birth, criticizing the procedures commonly applied in the 1950s and 1960s and proposing innovative practices aimed to eliminate the 'violence' of ordinary routines (2008). Combining the interests of his two predecessors, Michel Odent created the first salle sauvage (wild room) at the hospital of Pithivier where women could give birth in a space similar to their home and experience together with their baby the better conditions for the beginning of life. Since the publication of the work Bien-naître (1977), he became one the main supporters of the movement towards the 'demedicalisation' of childbirth in France as well as in several other European countries (Kniebiehler 2007) and is still a major inspiring figure for the advocates of homebirth and more broadly of a 'de-technicised' model of birth.

As this rough genealogy indicates, until the 1960s, women played a secondary role in the production of the 'natural childbirth' model. It was only when representatives of second wave feminism embraced the 'natural birth' movement against the increasing medicalisation of childbirth and more generally of women's health that female figures emerged, such as Ina May Gaskin (Davis-Floyd 1992, Gaskin 1975, Wertz and Wertz 1977). Harsh critiques were addressed to obstetrical technologies and hospitalised births that were seen as allowing male physicians to exert control over women's bodies, depriving them of the empowering and intimate experience of giving birth naturally (Annandale and Clark 1996, Arms 1975, Oakley 1984). Several scholars, activists, midwives and women, especially in the United States and in the United Kingdom but also in France and in Italy, criticised the medical system for being male-dominated, patriarchal, and oppressive. They claimed that childbirth, one of the main female creative powers, was expropriated by male physicians using technology and professional authority, preventing women from fully experiencing the crucial personal and social experience of giving birth. Their hands and legs strapped to their beds, hooked up to IV fluid, put under the surveillance of continuous foetal monitoring, numbed from chest to feet or even made unconscious, women were unable to realise their power of giving birth to a new life and were reduced to passive individuals, whose competences and abilities were denied by medical representatives (Katz Rothman 1980, Scully 1980, Wertz and Wertz 1977). Especially after 1968, a reactive model of childbirth emerged that drew on 'the idioms of "the natural" and "the normal"' and that "can be understood in historical and political terms as a response to the medical pro- 
fession's pathological approach to childbirth, as well as to the use of technology and application of norms that render birth a "high risk" event' (Beckett 2005: 254).

\section{...and the technocratic model of birth}

To understand the appearance of these critiques, it is necessary to think about the massive hospitalisation of childbirth and increasing application of technology to the reproductive process during the 20th century that is at the origin of deep social and professional changes. For example, in North America the profession of midwives disappeared for several decades (Davis-Floyd et al 2009, DeVries 1996, Saillant and O'Neil 1987), while in most European countries, midwives started to work mainly in hospital settings, relinquishing their autonomous activity (Marland and Rafferty 1997). As opposed to the beginning of the 20th century when midwives were the ordinary birth attendants for most women in Europe and North America, during the second half of the century in many countries they were replaced by physicians (Van Teijlingen et al 2004). All these transformations contributed to changing the imaginaries and models of childbirth, reinforcing a pathological definition of pregnancy and birth, which were represented as 'normal' only retrospectively, meaning that the whole process of conception, gestation, delivery could be declared normal only after it had come to an end (Carricaburu 2005, Murphy-Lawless 1998).

Tenants of the natural childbirth movement and feminists were not the only parties to react to the increasing medicalization of childbirth taking place in the second half of the 20th century. Among the advocates of humanised maternity care, there was the World Health Organisation who in the mid-1990s published a document warning health care professionals against the idea that birth can be declared normal only in retrospect (WHO 1996). One paragraph underlines that this view has the potential 'to turn a normal physiological event into a medical procedure' and to interfere 'with the freedom of women to experience the birth of their children in their own way, in the place of their own choice' (ibid: 2).

Although today there are important national variations (European Perinatal Health Report 2008), the interventionist model of childbirth associated with the medical profession is prevalent in many European countries and North America (Regalia and Bestetti 2010, Wagner 2006) where non-medicated births are becoming less common. The highly technological settings in which births occur and the pathological view of reproduction are generally identified as the main causes of the rising interventions registered in most high and middle-income countries. 
Definitions of 'normality' are related not only to evolving medical paradigms and technology, but also to national arrangements of health professions and more specifically to the division of labour between midwives and physicians. In certain states such as the Netherlands 'normal birth' is considered the province of midwives, while pathology is under obstetricians' supervision (DeVries 2005): a detailed Obstetric Manual (Verloskundig Vademecum) clearly defines what cases have to be transferred to the obstetricians while midwives or family physicians are in charge of the other women and babies. In other countries, such as France, since the reproductive process is considered only retrospectively normal, all pregnant women are put under medical supervision (Carricaburu 2005, 2007). Thus, the definition of 'normal birth' in each country is strongly affected by local professional arrangements and division of labour.

Despite the normalisation of medicated childbirth, in Western Europe and North America many advocates of 'natural birth' promoted and still do the idea that women have to rediscover the powers with which 'nature' has endowed them and fully realise their potentialities (Odent 2011, Schmid 2007, Wagner 2006). For the tenants of this view, giving birth naturally implies that women should recreate the mental and physical conditions the medical system has made them forget: they have to learn again to trust their body and realise their procreative strength, without making use of technology, avoiding physicians' interference and preferably choosing their home or an independent birth centre as the appropriate place for birth. Although not all advocates of natural birth were necessarily pleading for homebirth, the two movements developed at the same time and often coincided. In this sense, some authors distinguish between a holistic and a natural model of birth in which the emphasis is put more on the philosophy of the event than on the place where it takes place (Davis-Floyd 2009).

Yet, as noted by some feminist scholars during the 1990s, the model of 'natural birth' that emerged as a reaction to the patriarchal power of medical institutions, was paradoxically repositioning women into the traditionally feminine realm of motherhood, domesticity and nature (Badinter 2010, Beckett 2005, Gardey and Löwy 2000). Although for the advocates of homebirth the feminine pole of nature and domesticity has a positive connotation, the dichotomies nature/culture, female/male domestic space/public space were thus being reactivated instead of being addressed and disrupted using new metaphors and terms (Annandale and Clark 1995). 


\section{Some instances of nature in modern European thought}

To explore the meaning of 'nature' in modern European thought and its relationships with the terms culture and technology is an arduous task since the former was defined in very different ways according to the historical period, the discipline, and the authors considered. Therefore, in this section, I will attempt to explore only limited semantic areas of the concept of 'nature' that I think are important to understand the ideas of both 'natural birth' and 'natural caesarean'.

According to the French anthropologist Philippe Descola, the nature/culture dichotomy is a very specific way of conceptualising the relationships of human beings with their environment that not only is not universal but is equally uncommon, when compared with the symbolic systems of other cultures around the world (1996). The western notion that nature is 'a construct of culture' (Ortner 1974: 80) has a specific history and particular social, political and economic meanings. Furthermore, for Bruno Latour, the dichotomy nature/culture is the main feature of modern western thought that shapes our knowledge of the world regarded as divided into two realms: the natural and the cultural (1983). However, this dichotomy is an illusion, it does not correspond to actual practices in which human and non-human actors interact as, for instance, genetic engineering of plants and animals, and human assisted medical procreation show (Roepstorff et al 2003). These technologies constitute hybrid practices deeply subverting the nature/culture dichotomy and creating the new regime of 'biosociality' where knowledge and manipulation of nature coincide producing an 'artificial nature' (Rabinow 1996). Despite the biosocial character of our societies where both nature and culture have crossed the previous apparently clear-cut borders separating them, their imaginary opposition persists in various social domains such as in childbirth discourses and practices within which the association between woman and nature is still strong (Michie and Kahn 1996, Teman 2003).

While the nature/culture dichotomy is a construction of modern European scientific thought, the association between woman/nature, man/culture is also far from being a universal 'given' (MacCormack 1980: 6). The meaning of the dichotomy nature/culture we currently refer to has emerged during modern time especially during the 17th and 18th century when new political theories and scientific experimental practices were formulated that radically transformed European societies, paving the way to new perceptions of social life, a new division of labour, changes in gender roles, in productive activities, and in the political order (Jordanova 1996, Merchant 1983). Analysing the philosophical and scientific theories of 
18th century France about the relationships between nature and culture, Maurice and Jane Bloch identify four representations of nature. Nature was seen as 'a chronologically pre-social state', (usually positively connoted); as 'internal processes of the human body' that were either to be 'controlled by society' or developed by education in accordance with nature herself; and as 'the universal order which implies the harmonious coexistence of human nature and the external world of plants, animals and the countryside'; and as 'the way of life of primitive peoples' (1980: 27). Generally, for the French philosophers of Enlightenment, nature was a positive entity, a model for morality, science and social life. J. and M. Bloch point out that the coexistence of numerous definitions of nature derives from the fact that nature was outlined in opposition to something else and that this something else was 'extremely varied' (1980: 31): society tout court, corrupt society, upper class culture, the law, etc. It was therefore a 'category of challenge' rather than a well-defined entity. Interestingly, as I already noted, in the 1970s and 1980s the proponents of 'natural birth' used the term 'nature' in the very same way in opposition to the technocratic view of childbirth, while Dick-Read defined 'natural childbirth' as the original, primitive way of giving birth typical of 'tribal' or 'indigenous' women against 'cultured' or 'civilised' women. Hence, on the one hand, nature was used to contest a specific cultural configuration of ideas and practices crystallised by medical culture, on the other, to indicate an idealised natural state of primitive society.

The definitions analysed by J. and M. Bloch are obviously not exhaustive and are characteristic of a specific period of the European intellectual history. To understand the actual meaning of the nature/culture dichotomy in obstetrics, it is also necessary to mention the new perceptions of nature that emerged within the 'mechanist model' of the world epitomised by René Descartes and Francis Bacon. In the early 17th century the process of 'reification of nature' or the 'death of nature' (Merchant 1983) was accomplished. The organic view of nature, represented as an animated and ordered cosmos, was replaced by a 'system of dead, inert particles moved by external, rather than inherent forces, the mechanical framework itself could legitimate the manipulation of nature' (ibid: 183). According to Bacon, nature was to become the main object of scientific enquiry, if not of inquisition, a significant metaphor disclosing the aggressive and heroic attitude science was to adopt. Thus, he compared the secrets of nature to those of the witches under trial, since he considered that nature like a witch 'exhibits herself more clearly under trials and vexations of art (mechanical devices) than when left to herself' (quoted in Merchant 1983: 169). Since Bacon thought that nature was to be ex- 
plored, manipulated and exploited, scientists' mission was to uncover her secret rules, understand her errors and manipulate her in order to create something new and artificial through art (techné). Not only was nature not perfect, since it could make errors, but it was also a matter to be manipulated in order to create artificial products to be used by human beings in order to improve their life. The representation of nature as a dead matter, obeying to mechanic laws, subject to error and as a substance to be manipulated and exploited is at the origin of the modern scientific attitude. An aggressive approach towards nature developed together with the idea that it was legitimate to establish the human dominion over it in order to 'master' and 'manage' her forces. The mechanical model of nature allowed also a new social view of order: 'order was redefined to mean the predictable behaviour of each part within a rationally determined system of laws' (ibid: 193). Human bodies were to be seen as machines whose organic behaviour was ordered and predictable and hence subject to experts' possible modification and regulation in order to prevent or modify disorder and malfunctioning.

\section{Nature and culture in modern biomedical obstetrics}

If, in light of this short historical digression, we go back to modern obstetrics, the evolution of this branch of medicine becomes very significant insofar as it reveals socio-cultural features typical of western modernity. Its evolution shows how from a medical specialty studying the physiology of childbirth in 16th and 17th century France (Gélis 1991), practising on poor marginalised women and a technique used by barbers or surgeons for intervening in pathological cases - as illustrated by the history of forceps-, obstetrics became a discipline of the female body aimed at controlling its reproductive functions (Martin 1987). While by the end of the 18th century obstetrics had become a commodity for urban upper- and middle-class women and a lucrative profession for accoucheurs and medical men, in the 20th century it became a state-sponsored profession gaining authority over women's reproductive life (Arney 1982, Donnison 1977).

Despite its peculiarities, the evolution of obstetrics in the USA is a significant example to take into consideration, if we want to understand the general trend towards surgical births in Europe and in many middle-income countries, insofar as its natal system (Jordan 1993) has been one of the models for the rest of the world at least during the second half of the 20th century (Arney 1982). Although Europe had also produced technological innovations (ultrasound), new techniques (Lamaze method, 'natural childbirth'), and organisational models of work ('active ma- 
nagement of labour') in obstetrics, in many states of the old continent physicians have attentively observed the evolution of obstetric knowledge and technology in the USA, where many scientifically high-ranked journals of obstetrics and gynaecology are based. Here the 'technocratic model of birth' (Davis-Floyd 1992) has evolved much faster than in Europe thanks to the reorganisation of the medical schools after the publication of the Flexner report in 1910 (Wertz and Wertz 1977), the following institutionalisation of the obstetric profession (Walzer Leavitt 1986, Summey 1986) at the expenses of all other categories of birth attendants (Rooks 1997) and the adoption of a pathological model of birth (Hahn 1987, Jordan 1993). While at the beginning of the 20th century midwives were subject to a defamation campaign and were eventually outlawed (DeVries 1996), the medical model of birth promoted by obstetricians became the only legitimate one (Katz Rothman 1982). A pathological representation of the reproductive process was to determine the future of American women: pregnancy and childbirth, defined as illnesses, were to become medical events to be put under the supervision and control of medical experts (Arney 1982; Ehrenreich and English 1973; Hahn 1987; Oakley 1980; 1984; 1993; Katz Rothman 1980). Following the professionalization of medicine over the 20th century (Freidson 1970), the complete eradication of midwives, who were the main competitors of the newly institutionalised body of (male) obstetricians and of their paradigm of knowledge, marked the victory of the pathological representation of childbirth. Obstetricians heavily pushed the pathologic culture of birth, because obstetrics would have never achieved respect as a profession until 'the pathologic dignity of pregnancy' was recognized (Cyr 2006: 933). Thus, obstetrician-gynaecologists succeeded in imposing an interventionist attitude during pregnancy and birth and in promoting an increasing technologisation of the reproductive process (Donnison 1977, Walzer Leavitt 1986). Although a detailed history of the evolution of American obstetrics in the modern period is beyond the scope of this paper, the mentioned features are crucial to explain why the technocratic model of birth (Davis-Floyd 1992) dominates in the USA as well as in many other countries and how C-section, a major surgical procedure entailing risks for mothers and babies, has become a very ordinary way of giving birth for more than 30 per cent of women in many high- and middle- income countries (Davis-Floyd et al 2009). Indeed 'cesarean section in the United States is merely one dimension of an international trend towards medical specialists for the management of birth' (Sargent and Stark 1987: 1270). With few exceptions such as the Scandinavian countries, the Dutch model and the natal system of New Zealand (DeVries 2005, Hendry 2009), the aim of modern obstetrics has become not only 
to save mothers and babies affected by pathological conditions but also to supervise and control the process of childbearing. In order to ensure the control of the reproductive process, important efforts have been put in elaborating standards of normalcy, tools of measurements, and well defined time limits, as well as in creating the procedures necessary to 'manage' the physiological process of pregnancy and birth (De Koninck 1990; McCourt 2009). The notion of 'expectant management of birth' epitomises in a significant way the dominant interventionist philosophy among obstetricians: it indicates the non-interventionist clinical surveillance during the physiological evolution of labour. It is a paradoxical expression since, even the observation of a physiological event going on by itself according to its rhythm, is conceived of as an act dependent on the will of the physician, insofar as 'management' means 'to have under effective control, to contrive, to persuade, to do what one wants' (Wagner 1996: 15). Hence, although most births in well-off countries are likely to end with a healthy mother and a healthy baby, if left undisturbed (Odent 2004; Wagner 2006), obstetricians consider even observation as a form of intervention.

\section{Women's biology and childbirth}

While the idea of the body as machine is the basis on which modern medicine and more generally modern science is based (Lupton 1994), the philosophy underpinning current practice of obstetric management is affected by a gendered view of the female body. As shown among others by Emily Martin (1987) and Ludmilla Jordanova (1989), the female body is not a machine like the others: it is a defective machine, since it doesn't work as efficiently as the male body but needs the supervision and intervention of medical experts in order to accomplish its normal functions (Sherwin 1998). The differential treatment of women's and men's bodies in technocratic societies that involves the strong medicalisation of female sexuality and reproductive life, shows the gendered view of the roles assigned to men and women in the social order as well as the desire to exert control over some categories of individuals more than over others (Foucault 1979, Tabet 2010).

In the 1990s, Maria De Koninck published a study on women's attitudes towards C-section in Canada in which she emphasizes that most of the women she met had internalised the idea that their body was defective and potentially dangerous for the child they might bear. According to De Koninck, almost all of her interlocutors 'consider(ed) themselves incompetent and devoid of power in the domain of reproduction' (1990: 32) and regarded their body and their bodily behaviours as 
sources of risks. They perceived themselves as 'creators of problems rather than of children' (ibid: 34) and were not only inclined to accept, but often actively asked for experts' interventions. As already mentioned, in the last decades these attitudes have attracted the attention of many scholars who have highlighted the increasing acceptance both among women and birth assistants of medical interventions on pregnant bodies (Baston et al 2006, Habiba et al 2006, Klein et al 2011).

The spreading of this cultural attitude seems to be confirmed by my on-going fieldwork in a Swiss teaching hospital where women giving birth rarely enquire about the necessity of all the interventions they undergo and even more seldom express their wishes about the delivery they would like to experience. Most of the first-time mothers I meet do not have an idea of the kind of birth they would like to have and are afraid of what they hear from peers and family members or from information conveyed by the media. In the childbirth classes I have been attending, when asked about their expectations about childbirth, prospective first-time parents use words such as fear, pain, blood, cold hospital setting, lack of privacy, stress, fatigue, etc. After my two-year fieldwork in childbirth classes, I can safely argue that couples expressing a positive view of childbirth are an exception and that most of them would like only to be reassured and looked after.

Despite several differences in their attitudes and gestures, overall the midwives I have been observing follow hospital's routines that are highly interventionist, although they sometimes try to negotiate or subvert the protocols. While they are critical of some procedures, they seem to internalise a specific hospital culture that elicits automatic acts that could be avoided even in this highly technological setting. An example of a delivery I attended in the first months of 2013 is significant in that it shows the attitudes several midwives have developed working in this hospital setting. The parturient woman was a young primipara who, contrary to the 80 per cent of women giving birth in this maternity ward, did not want an epidural anaesthesia. Although mother and baby were doing well, the woman was subject to continuous foetal monitoring and was left in the lying position during labour and delivery. These two conditions are recommended only for women under epidural block while walking and moving freely are presented as important for ensuring a physiological delivery for which only intermittent EFM should be used. Moreover, at some point, the midwife, considering the woman's contractions too short, decided to start an intravenous drip of artificial oxytocin to accelerate the expulsion of the foetus. Since the woman was not eager to accept medications, she kindly but firmly told her that the drug was similar to the hor- 
mone her body produces and that it was going to help her. After some hesitations, the parturient woman accepted.

While in this Swiss hospital women willing to experience an un-medicated birth are rare, most of those I have observed accept hospital practices as obvious, normal and necessary and tend to transfer the entire responsibility of the birthing process to hospital staff. According to the interviews I have conducted with them and their partners, they are unwilling or feel unable to be in charge of the forthcoming delivery and of their child's care, especially when they are first-time parents.

\section{Conclusion: the manifold nature of 'natural C-section'}

Despite the high number of interventions during hospital 'normal birth' (Young 2009), some elements proposed by the 'natural birth' movement such as the participation of the father in the birth event, the skin-to-skin contact between mother and baby immediately after the delivery, early initiation of breastfeeding, etc. are today integrated in the hospital routines of many (Western) European countries and North America. Moreover, the philosophy of mother centred care has entered the field of obstetrics in the United Kingdom and several other high-income countries as a specific instance of the approach called patient centred medicine. The ideal hospital delivery, vaginal or by C-section, is thus one in which a selection of norms originating from these two contexts can be implemented. This means that birth attendants on the one hand, parents and child on the other can play the roles the present hospital model assign to them. While the extent to which both the technocratic 'normal birth' and 'natural C-section' are natural is subject to debate, if by 'natural' we intend an un-medicated event, it is nevertheless interesting to analyse the contradictory concepts of 'nature' entailed in today's obstetrics. As shown in this work, these concepts are rooted in European modern philosophical and scientific traditions and are part of a bundle of social and cultural ideas about nature which have had a substantial impact on social practices related to the human body and more specifically to childbirth. I have identified three main semantic areas of the word nature entailed in the concept of 'natural caesarean'. First, among the basic principles of obstetrics is the idea that nature (the body) is an entity made of substances that can be measured, manipulated, regulated and even improved to respond to specific human needs. Second, the general medical conception of the human body as machine (Armstrong 1983) is coupled with the gendered view of the female body developed by the modern medical tradition: 
the latter is deemed a defective and dysfunctional machine that can break up and hence needs to be managed and repaired (Martin 1987). Third, as mentioned above, nature is a 'category of challenge' (Bloch and Bloch 1980) alluding to an ideal moral or social state opposed to a corrupted or degenerated situation. This last semantic area of the word nature is particularly well represented in the various 20th century medical and feminist traditions that have criticized the increasing medicalization of the reproductive process. Current obstetrical practices and definitions in many Western European countries have integrated some elements of the philosophy of 'natural childbirth' and mother centred care but only insofar as they do not subvert the ordinary hospital routines. 'Natural C-section' is thus a concept entailing the history of a compromise between different philosophies of childbirth entailing different views of the (female) body, reproduction and the role health professional and technologies shall play in it. It expresses a pacified version of a more tumultuous story that current notions of 'normal or natural birth' allude to, without unveiling the complexity of the debate I have partially evoked in the previous pages.

\section{References}

Armstrong, D. (1983). Political Anatomy of the Body. Medical knowledge in Britain in the twentieh century, Cambridge, UK: Cambridge University Press.

Arney, W. (1982). Power and the Profession of Obstetrics, Chicago: University of Chicago Press. Badinter, E. (2010) Le conflit: la femme et la mère. Paris: Flammarion.

Beckett, K. (2005) Choosing cesarean. Feminism and the politics of childbirth in the United States'. Feminist Theory, 6 (3), 251-75.

Behague, D. (2002) Beyond the simple economics of cesarean section : birthing women resistance to social inequality. Culture, Medicine and Psychiatry, 26, 473-507.

Bloch, J., Bloch M. (1980) Women and the dialectis of nature in eighteenth-century French thought, in C. MacCormack \& M. Starthern (Eds.), Nature, Culture and Gender, (pp. 2541). Cambridge, UK: Cambridge University Press,.

Bridgman Perkins, B. (2004), The Medical Delivery Business. New Brunswick and London: Rutgers University Press.

Carricaburu, D. (2005). De la gestion technique du risque à celle du travail: l'accouchement en hôpital public. Sociologie du travail, 47, 245-62.

Carricaburu, D. (2007). De l'incertitude de la naissance au risque obstétrical: les enjeux d'une définition. Sociologie et sociétés, 39 (1), 123-44.

Coslett, T. (1994). Women Writing Childbirth: Modern Discourses of Motherhood, Manchester and New York: University of Manchester Press. 
Cyr, R. M. (2006). Myth of the ideal cesarean section rate: commentary and historic perspective. American Journal of Obstetrics and Gynaecology, 194 (4), 932-36.

Davis-Floyd, R. (1992). Birth as an American Rite of Passage. Berkeley and London: University of California Press.

Davis-Floyd, R. (1994). The technocratic body: American childbirth as cultural expression. Social Science and Medicine, 38(8), 1125-1140.

Davis-Floyd, R. (1996). The technocratic body and the organic body: hegemony and heresy in women's birth choices, in C. Sargent \& C. B. Brettell (Eds.), Gender and Health. An international perspective (pp. 123-166). Upper Saddle River: Prentice Hall.

Davis-Floyd, R., Barclay L., Daviss, B-A., Tritten, J. (Eds) (2009). Birth Models that Work. Berkeley and Los Angeles: University of California Press.

Darra, S. (2009). 'Normal', 'natural', 'good' or 'good enough' birth: examining the concepts. Nursing Inquiry, 16 (4), 297-305.

Declercq, E. (1998). 'Changing childbirth' in the United Kingdom: lessons for U.S. health policy. Journal of Health Politics, Policy and Law, 23 (5), 833-59.

Declercq, E., Young, R., Cabral, H., Ecker, J. (2011) Is a Rising Cesarean Delivery Rate Inevitable? Trends in Industrialized Countries, 1987 to 2007. Birth 38 (2), 99-104.

De Koninck, M. (1990). La normalisation de la césarienne, la résultante de rapports femmesexperts. Anthropologie et sociétés, 14 (1), 25-41.

Descola, Ph., Palsson, G. (Eds.) (1996). Nature and Society. Anthropological Perspectives. London and New York: Routledge.

De Vries, R. (1996). Making Midwives Legal. Childbirth, Medicine, and the Law. Columbus: Ohio State University Press.

De Vries, R. (2005). A Pleasing Birth. Midwives and Maternity Care in the Netherlands. Philadelphia: Temple University Press.

Dick-Read, G. (1985) [1944]. Childbirth Without Fear. New York and Cambridge: Perennial Library.

Donnison, J. (1977). Midwives and Medical Men: A History of Interprofessional Rivalries and Women's Rights. London: Heinemann.

Downe, S., (Ed.) (2008). Normal Childbirth. Edinburgh and London: Churching Livingstone Elsevier.

Edwardes, C., (2009). The new natural caesarean, The Times, 4 April 2009.

Ehrenreich, B. \& English, D. (1973). Witches, Midwives and Healers : A History of Women Healers. Old Westbury NY: The Feminist Press.

European Perinatal Health Report (2008) <http://www.europeristat.com>, accessed 24.09.2010.

Foucault, M, (1979). The History of Sexuality, Vol. 1, London: Allen Lane.

Freidson, E. (1970). Profession of medicine: a study of the sociology of applied knowledge. New York: Harper \& Row.

Gamble, J., D. K. Creedy, et al (2007). A critique of the literature on women's request for cesarean section. Birth, 34 (4), 331-40.

Gammeltoft, T. (2007). Sonography and Sociality. Medical Anthropology Quarterly, 21 (2), 13353.

Gammeltoft, T. (2008). Figures of transversality: state power and prenatal screening in contemporary Vietnam. American Ethnologist, 35 (4), 570-87.

Garday, D., Löwy, I. (Eds.)(2000). L'invention du naturel. Les sciences et la fabrication du feminin et $d u$ masculin. Paris: Editions des archives contemporaines. 
Georges, E. (1996) Fetal ultrasound imaging and the production of authoritative knowledge in Greece. Medical Anthropology Quarterly, 10 (2), 157-75.

Gélis, J. (1988). La sage-femme ou le médecin. Une nouvelle conception de la vie. Paris: Fayard.

Green, J. \& Baston, H. (2007). Have women become more willing to accept obstetric interventions and does this related to mode of birth? Data from a prospective study. Birth, 34 (1), 6-13.

Goer, H. (1999). The Thinking Woman's Guide to a Better Birth. New York: A Perigee Book. Goer, H. (2004), Humanizing Birth. A global grassroots movement. Birth, 31(4), 308-314.

Habiba, M. \& Kaminsky, M. (2006). Caesarean section on request: a comparison of obstetricians' attitudes in eight European countries. British Journal of Obstetrics and Gynaecology, 113 (6), 647-56.

Hahn, R., A. (1987). Divisions of labor: obstetrician, woman and society in Williams Obstetrics, 1903-1985. Medical Anthropology Quarterly, 1 (3), 256-82.

Hendry, C. (2009). The New Zealand maternity system. In R. Davis-Floyd, L. Barclay, B-A. Daviss, B-A., Tritten, J. (Eds) (2009). Birth Models that Work. Berkeley and Los Angeles: University of California Press.

Jacques, B. (2007). Sociologie de l'accouchement. Paris: Presses Universitaires de France.

Jordan, B. (1993). Birth in Four Cultures. A Cross-cultural Investigation of Childbirth in Yucatan, Holland, Sweden, and the United-States. Long Grove: Waveland Press, Inc.

Jordanova, L. (1989). Sexual Visions: images of gender in science and medicine between the eighteenth and twentieth centuries. New York and London: Harvester Wheatsheaf.

Jukelevics, N. (2008). Understanding the Dangers of Cesarean Birth. Making informed decision. Westprot and London: Praeger.

Katz Rothman, B. (1982). In Labor. Women and power in the Birthplace. New York and London: W. W. Norton \& Co.

Katz Rothman, B. (1987). The Tentative Pregnancy. Prenatal Diagnosis and the Future of Motherhood. New York: Penguin Books.

Klein, M., Liston, R, Fraser, W., Baradaran, N. et al (2011). 'Attitudes of the new generation of Canadian obstetricians: how do they differ from their predecessors? Birth Vol. 38 No. 2, pp. 129-139.

Knibiehler, Y (2007) Accoucher. Femmes, sages-femmes et médecins depuis le milieu du XXe siècle. Paris: Editions ENSP.

Lamaze, F. (1956). Qu'est-ce que l'accouchement sans douleur par la methode psychoprofylactique. Paris: Savoir et connaître

Latour, B. (1983). Comment redistribuer le grand partage'. Revue de synthèse, 104 (110), 20336.

Leboyer, F. (2008) [1974]. Pour une naissance sans douleur. Paris: Seuil.

Lock, M., Kaufert, P. (Eds.) (2001). Menopause. Local biologies, and cultures of aging. American Journal of Human Biology, 13, 494-504.

Lupton, D. (1994). Medicine as Culture. Illness, Disease and the Body in Western Societies. London, Thousand Oaks and New Delhi: Sage Publications.

MacCormack, C. \& Starthern, M. (Eds.) (1980). Nature, Culture and Gender. Cambridge: Cambridge University Press.

MacCourt, C. (Ed.) (2009). Childbirth, Midwifery and Concepts of Time. New York and Oxford: Berghahn Books. 
MacDonald, M. (2007). Natural birth and gender expectations. In At Work in the Field of Birth (pp. 93-126). Nashville: Vanderbilt University Press,.

Maffi, I. (2012). Women, Health and the State in the Middle East. Culture and Politics of Childbirth in Jordan. London: I.B. Tauris.

Maffi, I. (forthcoming). Les cours de préparation à la naissance dans un hôpital suisse. Entre logiques institutionnelles, posture des sages-femmes et autonomie des couples. In Maffi, I., Burton-Jeangros, C., Hammer, R., (Eds.) Accompagner la grossesse et l'accouchement. Savoirs et pratiques professionnelles en Suisse, Lausanne, Bangkok: BSN Press.

Making Normal Birth a Reality. Consensus Statement from the Maternity Care Working Party (2007), <http://www.rcog.org.uk/files/rcog-corp/uploaded-files/JointStatmentNormalBirth2007.pdf $>$, accessed 15.2.2011.

Mansfield, B. (2008). The social nature of natural childbirth'. Social Science and Medicine. 66, 1084-1094.

Marland, H. \& Rafferty, A.M. (Eds.) (1997). Midwives, Society and Childbirth. Debates and Controversies in the Modern Period. London and New York: Routledge.

Martin, E. (1987). The Woman in the Body. A Cultural Analysis of Reproduction. Boston: Beacon Press.

Merchant, C. (1983). The Death of Nature: Women, Ecology and the Scientific Revolution. New York and San Francisco: Harper and Row .

Michie, H. \& Cahn, N. R. (1996). Unnatural births: caesarean sections in the discourse of the 'natural childbirth' movement. In C. Sargent \& C. B. Brettell (Eds.). Gender and Health. An International Perspective (pp. 44-56). Upper Saddle River: Prentice Hall.

Moscucci, O. (1993) The Science of Woman: Gynaecology and Gender in England, 1800-1929. Cambridge and New York: Cambridge University Press.

Moscucci, O. (2003). Holistic obstetrics: the origins of 'natural childbirth' in Britain. Postgraduate Medical Journal, 79, 168-73.

Murphy-Lawless, J. (1998). Reading Birth and Death: A History of Obstetric Thinking. Cork: Cork University Press.

Oakley, A. (1980). Women Confined. Towards a Sociology of Childbirth. New York: Schocken Books

Oakley, A. (1984). The Captured Womb. A history of medical care of pregnant women. Oxford: Basic Blackwell.

Oakley, A. (1993). Essays on Women, Medicine $\mathcal{E}$ Health. Edinburgh: Edinburgh University Press.

Odent, M. (1977). Bien-naître. Paris: Seuil.

Odent, M. (2001). The Scientification of Love. London: Free Association Books.

Odent, M. (2004). The Caesarean. London: Free Association Books.

Odent, M. (2011). Le bébé est un mammifère. Paris: Editions de l'instant present.

Ortner, S. B. (1974). Is Female to Male as Nature Is to Culture?. Feminist Studies. 1, 5-31.

Rabinow, P. (1996). Artificiality and enlightenment: from sociobiology to biosociality'. In Essays in the Anthropology of Reason (pp. 91-111). Princeton: Princeton University Press.

Roepstorff, A., Bubandt, N., Kull, K. (Eds.) (2003). Imagining Nature: Practices of Cosmology and Identity. Aarhus: Aarhus University Press.

Rooks, J. (1997). Midwifery and Childbirth in America. Philadelphia PA: Temple University Press. 
Royal College of Midwives, 'Woman-Centred Care. Position Statements' <http://www.rcm. org.uk/college/policy-practice/position-statement/>, accessed, 28.02.2013.

Saillant, F \& O’Neill, M. (Eds.) (1987). Accoucher autrement. Repères historiques, sociaux et culturels de la grossesse et de l'accouchement au Québec. Montréal: Les éditions Saint-Martin.

Sargent, C. \& Stark, N. (1987). Surgical birth: interpretations of caesarean delivery among private hospital patients and nursing staff. Social Science and Medicine. 25 (12), 1269-76.

Schmidt, V. (2007). Salute e nascita. La salutogenesi in gravidanza. Milano: Urra.

Scully, D. (1980) Men Who Control Women's Health. Boston: Houghton Mifflin Company.

Sherwin, S. (1998). The Politics of Women's Health. Exploring Agency and Autonomy. Philadelphia: Temple University Press.

Smith, J., F. Plaat, Fisk N.M. (2008). The natural caesarean: a woman-centred technique. British Journal of Obstetrics and Gynaecology, 115, 1037-42.

Summey, P (1986). Cesarean birth. In P. Eakins (Ed.), The American Way of Birth (pp. 175-95). Philadelphia: Temple University Press.

Tabet, P. (2010). La construction sociale des inégalités de sexe: des outils et des corps. Paris: l'Harmattan.

Teman, E. (2003). The medicalization of nature in the 'artificial body': surrogate motherhood in Israel. Medical Anthropology Quarterly, 17 (1), 78-98.

Van Hollen, C. (2003). Birth on the Threshold. Childbirth and Modernity in South India. Berkeley and Los Angeles: University of California Press.

Van Teijlingen, E. R. Lowis, G. W., McCaffery, P. G., Porter, M. (Eds.) (2004). Midwifery And The Medicalization Of Childbirth: Comparative Perspectives. New York : Nova Science Publishers.

Waltzer Leavitt, J. (1986). Brought to Bed. Childbearing in America. Oxford: Oxford University Press.

Wagner, M. (2000). Choosing Caesarean section. Lancet, 356, 1677-80.

Wagner, W. (2006). Born in the USA. How a Broken Maternity System Must Be Fixed to Put Mothers and Infants First. Berkeley and Los Angeles: University of California Press.

Wertz, R. W. \& Wertz, D. C. (1977). Lying-In. A history of childbirth in America. New York: The Free Press.

World Health Organisation (1985). Appropriate technology for birth. Lancet, 2, 436-7.

World Health Organisation (1996). Care of Normal Birth: a Practical Guide. Geneva: WHO.

Young, D. (2009). What is normal birth and do we need more statements about it?. Birth, 36 (1), 1-3.

Thomsen,T.T., Hoffman,B., Jensen,A.B., Høyer,K., Ballegaard,S.A., Aarhus,R., Pedersen,I.K., Østergaard,E.B., \& Sångren,H. (2009). Krop og teknologi. (pp.1-130). 